\title{
A quantitative cytological study of polyovular follicles in mammalian ovaries with particular reference to the domestic bitch (Canis familiaris)
}

\author{
Evelyn Telfer and R. G. Gosden \\ Department of Physiology, University Medical School, Teviot Place, Edinburgh EH8 9AG, U.K.
}

\begin{abstract}
Summary. The incidence of polyovular types in the growing follicle population was estimated using quantitative cytology. Of 15 species studied, polyovular follicles were recorded in the following species and in ascending order of abundance: rabbits, rhesus monkeys, humans, cats, dogs. The incidence in bitches was $14 \%$ in animals aged $1-2$ years but only $5 \%$ at $7-11$ years old. The frequency of the various types of polyovular preantral follicle varied inversely with the numbers of oocytes per follicle and the probability of finding a follicle with more than 5 oocytes was remote. In young ovaries the frequency was constant in the early stages of growth but decreased in the largest preantral stage. The pattern in ageing ovaries was, by contrast, one of declining frequency such that few if any polyovular types completed development. The ovary of the ageing bitch was also characterized by a higher incidence of degenerating follicles and a much smaller pool of primordial stages. Polyovular follicles were larger than uniovular types at comparable stages which were defined by the number of granulosa cell layers. Their oocytes were smaller but the overall ooplasmic mass was increased with a corresponding increase in the mass of granulosa cells.
\end{abstract}

\section{Introduction}

The majority of ovarian follicles contain only a single oocyte although many authors have drawn attention to instances in which two or more oocytes are present. Binovular and multiovular follicles (henceforward called polyovular follicles) have been reported sporadically in most mammalian species since Von Baer's discovery of the oocyte (Von Baer, 1827). The early literature on polyovular follicles was primarily descriptive histology and was reviewed by Hartman in 1926, but subsequent work has mainly contributed to the range of species in which these are found rather than attempting the larger task of quantitation (see Mossman \& Duke, 1973). Progress towards obtaining reliable data and, hence, making inferences about the origin and developmental potential of these structures has undoubtedly been hampered by the problem that polyovular follicles tend to occur infrequently in most species.

Interest in polyovular follicles has stemmed from two questions, namely, their ontogenesis and their contribution to fecundity. These follicles have frequently been regarded as pathological entities and this has led many investigators to pay attention to the incidence of oocyte death and the role of sex steroid and gonadotrophin concentrations (Lane, 1938; Bodemer \& Warnick, 1961a; Kent \& Mandel, 1970). The changing hormonal 'balance' after puberty provided an explanation for the apparent fall in the incidence of polyovular follicles as animals matured (Kent, 1960). The early inquiries were, however, influenced by a limited knowledge of reproductive endocrinology and the widespread and erroneous belief that oocytes are formed continually throughout life. Polyovular follicles are also of interest because they present a natural experiment in which the general rule of one oocyte: one follicle has been altered with possible developmental significance for the follicle and its various compartments. 
The present study was devised to obtain quantitative data about polyovular follicles at different developmental stages in order to identify patterns, to draw inferences about ontogenesis and to make predictions about the contribution of these structures to ovulation at different ages. The data also provided an opportunity to make an initial judgment whether the development of polyovular follicles is substantially different from that of uniovular types.

These objectives depended on the availability of ovaries having a sufficiently high incidence of polyovular follicles. Since published reports rarely present numerical data and where these exist they are not based on a standard classification of follicles, a survey was carried out to identify a suitable species for detailed study. The domestic bitch was chosen on the basis of having a higher frequency of polyovular follicles than did any of the other species studied.

\section{Materials and Methods}

Incidence of polyovular follicles in different species. The proportions of growing follicles containing 2, 3, 4 or more oocytes were estimated using histological specimens which had been collected during an earlier study (Gosden \& Telfer, 1987). Fifteen species were examined in toto (see Table 1) with at least four young adult individuals representing each species except for man for which only one ovary from each of two patients was available. A minimum of 1000 follicles was examined for each species. The nucleolus of the oocyte was used as a marker for counting the follicles and, when appropriate, adjacent sections were searched to determine the complete set of oocytes in polyovular follicles.

On the basis of the findings, additional specimens were obtained from bitches for further studies.

Source and preparation of specimens. Ovaries were obtained during routine veterinary spaying of cross-bred bitches weighing 3.8-21.5 kg. The animals comprised a group of 10 virgins aged $1-2$ years old and another group of 5 aged 7-11 years with reproductive histories. All animals were anoestrous and healthy at the time of surgery.

The reproductive tracts were immersed in buffered formalin for transit to the laboratory where the ovaries were dissected and fixed in Susa for $24 \mathrm{~h}$. One ovary from each pair was prepared by serially sectioning at $10 \mu \mathrm{m}$ and staining with haematoxylin and eosin.

Classification of follicles in bitch ovaries. Each follicle was classified according to the 'stage' in the developmental continuum ('stage') and the 'type' of follicle, as defined by the numbers of oocytes present. The follicle stages were based on the scheme used for rat ovaries by Mandl \& Zuckerman (1951) in which the appearance of the oocyte and the number and morphology of the granulosa cell layers are the defining variables (Fig. 1). The follicle types were defined according to the numbers of oocytes present; i.e. type 1 contained a single oocyte, type 2 contained two oocytes, and so on to type $5+$. Follicles were also distinguished according to their qualitative appearance: those having a wrinkled oocyte(s) and/or pycnotic granulosa cells were deemed to be degenerating ('atretic'). The data presented in the 'Results' comprise only follicles which appeared to be healthy because it was frequently not possible to assign degenerating follicles to a definite stage and type.

Protocol for counting bitch follicles. A sampling frequency of every 20th serial section was used because a single bitch ovary may yield more than a thousand $10 \mu \mathrm{m}$ sections. Primordial (non-growing) follicles and uniovular growing stages were counted using the oocyte nucleolus as a marker as this is small and discrete and normally single. The total number of follicles per animal was estimated by multiplying by (a) the sampling frequency (20), (b) a correction factor because of overcounting biasses, and (c) 2 to obtain the value for a pair of ovaries. The correction factor was obtained by a standard method based on the mean diameter of the nucleolus and the section thickness (Mandl \& Zuckerman, 1951).

Primordial follicles could not be characterized as polyovular because the boundaries of these small follicles are not easily resolved using the light microscope. The procedure for counting the numbers of polyovular growing follicles differed from that used with the uniovular types. Having identified at least one marker in a polyovular follicle, adjacent sections were searched to determine the total complement of markers (oocytes) present. In general, this added step was important only in larger follicles (stage V) in which the oocytes were more widely dispersed. The product of the raw counts and the sampling frequency produces the estimated numbers of polyovular follicles in one ovary. This method may, however, overestimate the actual number present because follicles carrying a larger number of dispersed oocytes are more likely to be detected in the samples. This problem is not amenable to a simple theoretical approach for obtaining correction factors, as has been the case for uniovular follicles, because there are several markers present and any given section may not contain all of them. Since an examination of every section is impractical, a correction factor was obtained by the following empirical method. The number of polyovular follicles at an intermediate stage (III) was counted in 200 consecutive sections in each of 3 ovaries. The correction factor was obtained by dividing this number by the number obtained from sampling every 20 th section. Pilot studies showed that the proportions of follicles that were polyovular differed only marginally after applying the corrected values.

Measurements of follicle and oocyte dimensions. A random sample of 206 uni- and polyovular follicles was used to measure follicles and oocytes in their equatorial planes, as follows. (1) The mean follicular diameter was obtained by 


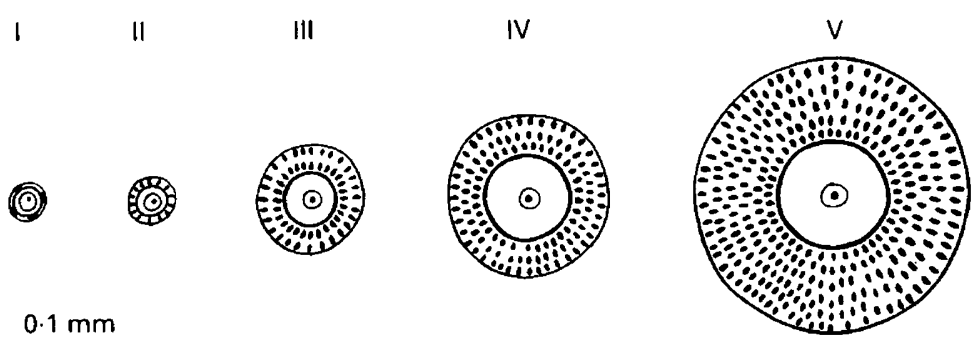

Fig. 1. Schematic representations of preantral stages of follicular growth in bitch ovaries. The figure is drawn to scale and depicts only the uniovular follicle types.

measuring the maximum and minimum diameters using a microscope fitted with an ocular micrometer. The boundary of the follicle was defined by the outer circumference of the granulosa layer because the theca layer was indistinct in small follicles. (2) The diameters of oocytes and their nuclei were measured by a similar method. (3) Precise measurements of nucleolar diameters were obtained using an image-shearing device with oil immersion optics $(\times 1000)$ which provide a theoretical resolution of less than $0 \cdot 2 \mu \mathrm{m}$ (Swyte \& Rosberry, 1977).

\section{Results}

\section{Incidence of polyovular follicles in different species}

Uniovular follicles were the predominant type in the animals investigated. In 10 of the 15 species studied polyovular follicles were not detected although further and more extensive searches sometimes revealed small numbers of binovular types. The incidence of polyovular follicles in the other 5 species varied from $1 \%$ in the rabbit to $14 \%$ in the bitch; in human ovaries $3 \%$ of the follicles were either bin- or trinovular (Table 1). In each ovary the numbers of follicles of the different types varied inversely with the numbers of oocytes that they contained.

\section{The follicle profile of the anoestrous bitch ovary}

The follicles were confined to a narrow cortical band and the large volume of medullary tissue was afollicular and fibrous. Primordial follicles were frequently clustered but the boundaries of these small groups were not clearly circumscribed at the light microscope level (Fig. 2); consequently, groups of oocytes which may be predisposed to polyovular development could not be identified at this stage. Polynuclear oocytes were rarely encountered. Some primordial follicles appeared to be in the process of degeneration but atresia was more clearly characterized in growing follicles in which the oocyte appeared wrinkled and the granulosa cells pycnotic. Polyovular follicles (Fig. 3) could not be confused with atretic follicles containing a fragmented oocyte since a distinct nucleus was present in each of the oocytes. About $10 \%$ of the growing follicle population in young ovaries was atretic by these criteria, as opposed to $30 \%$ in the older bitches. The proportions of the different types of polyovular development were remarkably consistent from stage to stage. Anovular 'follicles' were observed occasionally in ageing ovaries; the space formerly occupied by the oocyte had been invaded by granulosa cells.

The total numbers of primordial follicles per animal were highly variable (Table 2). The mean in young ovaries was 85800 (s.e. 18600 ) compared with only 2750 (s.e. 900) in the older group $(P<0.05$ using the Kruskal Wallis non-parametric test). The primordial follicle was the most abundant stage present and, like the other stages, suffered substantial losses during ageing. In contrast to these reductions, the percentage of follicles in the growing stages rose substantially since the relative age-dependent losses in the growing and non-growing sub-populations differed. 
Table 1. Frequency of polyovular follicles in 15 mammalian species

\begin{tabular}{|c|c|c|c|c|}
\hline \multirow{2}{*}{\multicolumn{2}{|c|}{ Species }} & \multicolumn{3}{|c|}{$\begin{array}{l}\% \text { of growing follicles } \\
\text { containing: }\end{array}$} \\
\hline & & \multirow{2}{*}{$\begin{array}{c}2 \\
\text { oocytes }\end{array}$} & \multirow{2}{*}{$\begin{array}{c}3 \\
\text { oocytes }\end{array}$} & \multirow{2}{*}{$\begin{array}{c}4+ \\
\text { oocytes }\end{array}$} \\
\hline Common name & Specific name & & & \\
\hline Bandicoot & Isoodon macrourus & $<0 \cdot 10$ & $<0 \cdot 10$ & $<0 \cdot 10$ \\
\hline Common shrew & Sorex araneus & $<0 \cdot 10$ & $<0 \cdot 10$ & $<0 \cdot 10$ \\
\hline Pipistrelle bat & Pipistrellus pipistrellus & $<0 \cdot 10$ & $<0 \cdot 10$ & $<0 \cdot 10$ \\
\hline Laboratory mouse (CBA) & Mus musculus & $<0 \cdot 10$ & $<0 \cdot 10$ & $<0 \cdot 10$ \\
\hline Woodmouse & Apodemus sylvaticus & $<0 \cdot 10$ & $<0 \cdot 10$ & $<0 \cdot 10$ \\
\hline Bank vole & Clethrionomys glareolus & $<0 \cdot 10$ & $<0 \cdot 10$ & $<0 \cdot 10$ \\
\hline Field vole & Microtus agrestis & $<0 \cdot 10$ & $<0 \cdot 10$ & $<0 \cdot 10$ \\
\hline Rat & Rattus norvegicus & $<0 \cdot 10$ & $<0 \cdot 10$ & $<0 \cdot 10$ \\
\hline Rabbit & Oryctolagus cuniculus & $0 \cdot 91$ & $<0 \cdot 10$ & $<0 \cdot 10$ \\
\hline Cat & Felis catus & 3.61 & 0.45 & $<0 \cdot 10$ \\
\hline Bitch & Canis familiaris & 8.89 & 2.97 & $2 \cdot 08$ \\
\hline Sheep & Ovis aries & $<0 \cdot 10$ & $<0 \cdot 10$ & $<0 \cdot 10$ \\
\hline Marmoset monkey & Callithrix jacchus & $<0 \cdot 10$ & $<0 \cdot 10$ & $<0 \cdot 10$ \\
\hline Rhesus monkey & Macaca mulatta & 1.49 & $0 \cdot 30$ & $<0 \cdot 10$ \\
\hline Human & Homo sapiens & $2 \cdot 72$ & $0 \cdot 19$ & $<0 \cdot 10$ \\
\hline
\end{tabular}

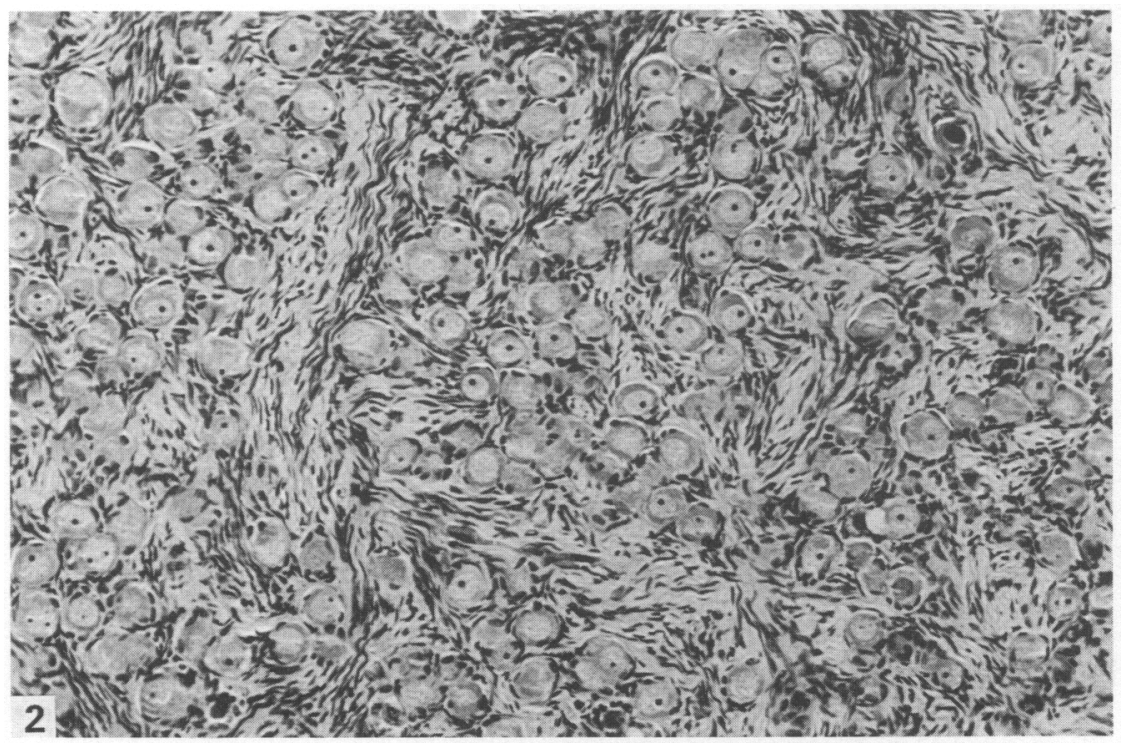

Fig. 2. The ovarian cortex of a young adult bitch which contains numerous primordial follicles in clusters. $\mathrm{H} \& \mathrm{E}, \times 160$.

Whereas in young animals only $10 \%$ of follicles were classified as growing, over $50 \%$ were growing in the older group.

Polyovular follicles were present in all animals with the single exception of a young bitch which, except when stated otherwise, has been included in the presentation of data. They were found at each of the four stages of preantral growth (II-V) in young ovaries and at stages II-IV in the other groups (Tables $3 \& 5$ ). Overall, their incidence was similar to that obtained during the pilot studies using a small sample (Table 1), being $14 \%$ in the young group but only $5 \%$ in the old animals. 


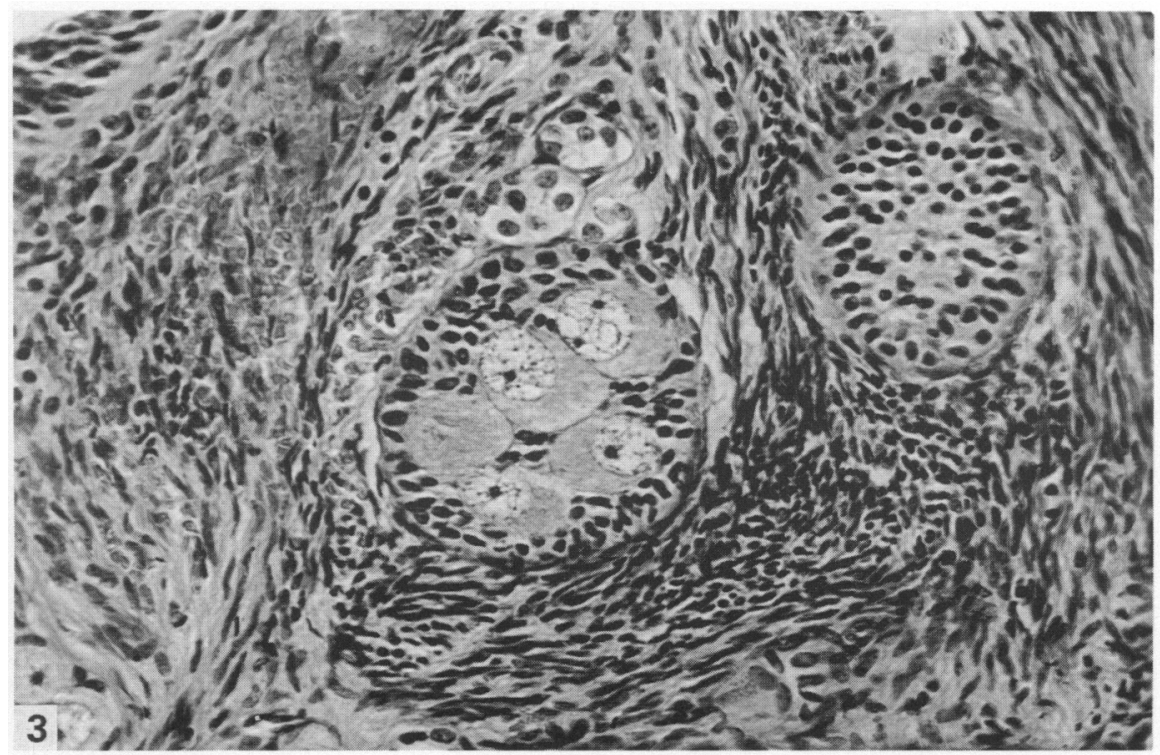

Fig. 3. Detail of the cortex of the bitch ovary showing a growing follicle containing 5 oocytes (centre). $\mathrm{H} \& \mathrm{E}, \times 320$.

Table 2. A quantitative profile of the follicle population of anoestrous ovaries in young adult and ageing bitches

\begin{tabular}{lcc}
\hline & $\begin{array}{c}\text { Young } \\
\text { animals }\end{array}$ & $\begin{array}{c}\text { Ageing } \\
\text { animals }\end{array}$ \\
\hline $\begin{array}{l}\text { No. of animals } \\
\text { Age range (years) }\end{array}$ & 10 & 5 \\
$\begin{array}{l}\text { No. of primordial follicles } \\
\text { (range) }\end{array}$ & $1-2$ & $7-11$ \\
$\begin{array}{l}\text { No. of growing follicles } \\
\text { (range) }\end{array}$ & $5400-214000$ & $1200-6150$ \\
$\begin{array}{l}\% \text { growing follicles } \\
\text { No. of polyovular growing } \\
\text { follicles (range) }\end{array}$ & $3470-13600$ & $1720-6770$ \\
$\%$ polyovular growing \\
follicles
\end{tabular}

†Excludes one animal in which polyovular follicles were absent.

Table 3. Numbers (and s.e.m.) of growing follicles in young bitch ovaries classified according to the stage of development and number of oocytes ('type')

\begin{tabular}{|c|c|c|c|c|c|}
\hline \multirow{2}{*}{$\begin{array}{c}\text { Follicle } \\
\text { stage }\end{array}$} & \multicolumn{5}{|c|}{ Follicle type } \\
\hline & 1 & 2 & 3 & 4 & $5+$ \\
\hline II & $4002(585)$ & $378(104)$ & $119(47)$ & $56(34)$ & $49(34)$ \\
\hline III & 2089 & $210 \quad(77)$ & $90(43)$ & $40(57)$ & $27(20)$ \\
\hline IV & $972(132)$ & $147 \quad(60)$ & $59(30)$ & 20 (13) & $5(5)$ \\
\hline $\mathrm{V}$ & $1251(209)$ & $128 \quad(60)$ & $13(14)$ & $4(3)$ & $2(2)$ \\
\hline
\end{tabular}




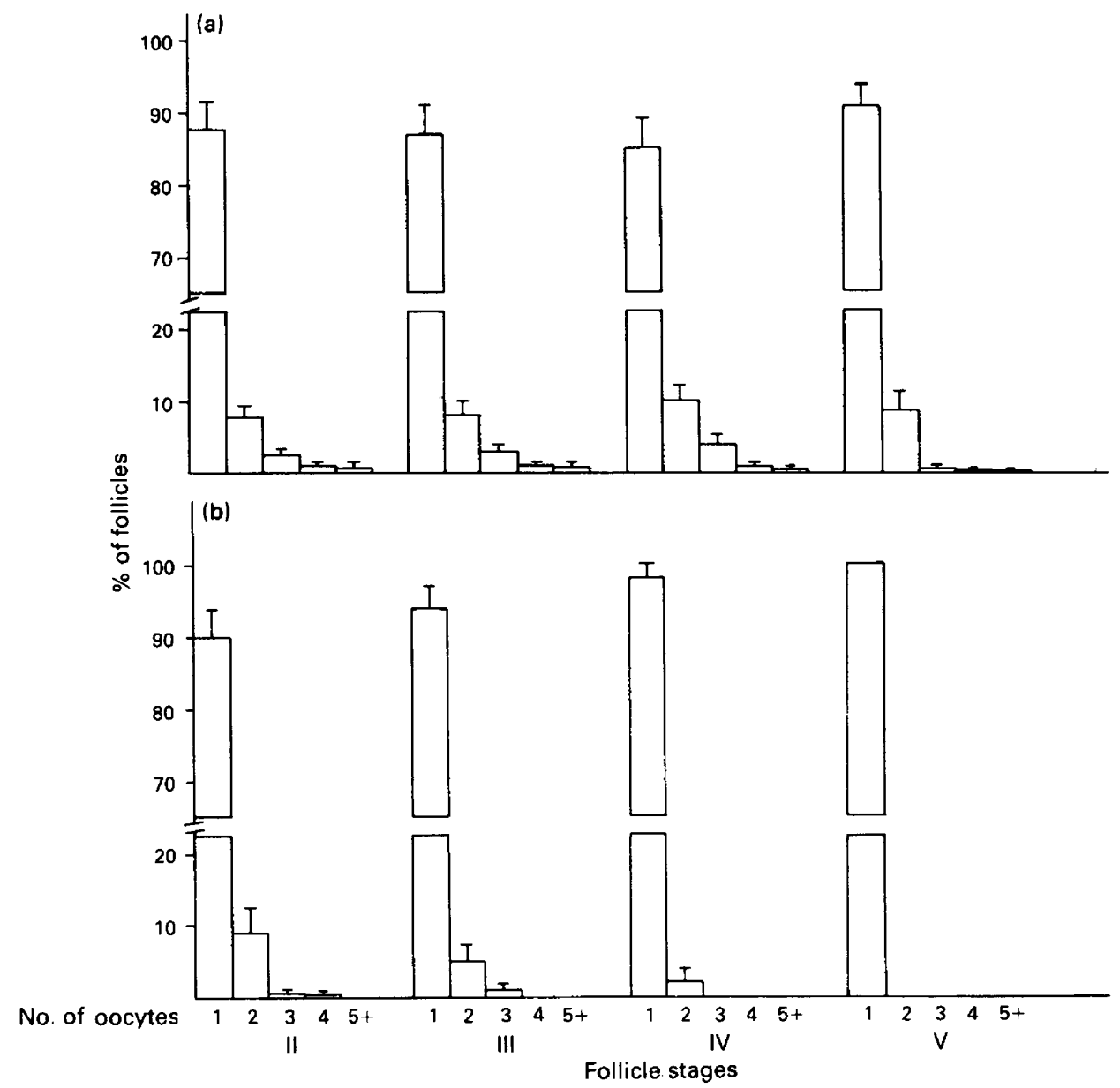

Fig. 4. Percentage frequency distribution at successive stages of development of polyovular follicles in ovaries of (a) young bitches $(\mathrm{N}=10)$ and $(\mathrm{b})$ ageing bitches $(\mathrm{N}=5)$. Values given are mean + s.e.m.

The consistent proportions of polyovular follicles from stage to stage were striking in view of the variable numbers of follicles present (Fig. 4a). In young animals, it was only at stage $V$ that the proportions of these follicles fell and this effect was restricted to types $3+(P<0.01)$. The numbers at any given stage appeared to decline approximately exponentially as the numbers of oocytes rose. Since estimating the incidence of follicles with more than 5 oocytes was hazardous because of sampling errors at low frequencies the tabulated results and histograms have not been extended beyond type $5+$ in which the less common types were combined. The largest number of oocytes observed in a single follicle was 9 in this series although up to 14 were observed in other bitches. A simple probability table was constructed to indicate the chances of encountering growing follicles of a given type and stage (Table 4). This demonstrates that the probability declines steadily from left to right as the numbers of oocytes increase, in contrast there is less variation on the vertical scale which represents successive stages of follicle growth. Clearly, a large number of follicles must be sampled to obtain reliable estimates of follicles with 4 or more oocytes.

The incidence of different follicle types in older bitches demonstrated a pattern similar to that described in the younger group (Fig. 4b) although there were two major differences between them. 
Table 4. Probability distribution for follicles in young bitch ovaries classified according to developmental stage and number of oocytes

\begin{tabular}{lcccrr}
\hline \multirow{2}{*}{$\begin{array}{c}\text { Follicle } \\
\text { stage }\end{array}$} & \multicolumn{5}{c}{ Follicle type } \\
\cline { 2 - 6 } & 1 & 2 & 3 & \multicolumn{1}{c}{4} & \multicolumn{1}{c}{$5+$} \\
\hline II & 0.414 & 0.040 & 0.013 & 0.006 & 0.005 \\
III & 0.216 & 0.022 & 0.009 & 0.004 & 0.003 \\
IV & 0.100 & 0.015 & 0.006 & 0.002 & $<0.001$ \\
V & 0.129 & 0.013 & 0.001 & $<0.001$ & $<0.001$ \\
\hline
\end{tabular}

Table 5. Numbers (and s.e.m.) of growing follicles in ageing bitch ovaries classified according to the stage of development and number of oocytes

\begin{tabular}{lrrrrr}
\hline \multirow{2}{*}{$\begin{array}{c}\text { Follicle } \\
\text { stage }\end{array}$} & 1 & 2 & 3 & 4 & $5+$ \\
\cline { 2 - 6 } & $1308(387)$ & $100(38)$ & $8(4)$ & $4(4)$ & 0 \\
\hline II & $828(270)$ & $30(15)$ & $4(4)$ & 0 & 0 \\
III & $343(174)$ & $4(4)$ & 0 & 0 & 0 \\
IV & $364(167)$ & 0 & 0 & 0 & 0 \\
V & & & &
\end{tabular}

Table 6. Probability distribution for follicles in ageing bitch ovaries classified according to developmental stage and numbers of oocytes

\begin{tabular}{|c|c|c|c|c|c|}
\hline \multirow{2}{*}{$\begin{array}{l}\text { Follicle } \\
\text { stage }\end{array}$} & \multicolumn{5}{|c|}{ Follicle type } \\
\hline & I & 2 & 3 & 4 & $5+$ \\
\hline II & 0.440 & 0.033 & 0.003 & 0.001 & $<0.001$ \\
\hline III & $0 \cdot 276$ & 0.010 & 0.001 & $<0.001$ & $<0.001$ \\
\hline IV & 0.114 & 0.001 & $<0.001$ & $<0.001$ & $<0.001$ \\
\hline V & $0 \cdot 122$ & $<0.001$ & $<0.001$ & $<0.001$ & $<0.001$ \\
\hline
\end{tabular}

Firstly, there was the overall reduction in numbers and incidence of polyovuly as was mentioned above. Secondly, the consistent proportions of polyovular follicles from stage to stage was lost. Despite having sampled hundreds of sections of ageing ovaries polyovular follicles were never detected at stage $\mathrm{V}$ and only a few binovular types were represented at the preceding stage (Table 5). The probability table suggests that the chance of finding a binovular follicle at the earliest stage of growth in older animals is only slightly lower than that for young ovaries whereas that of finding other types rapidly approaches zero (Table 6).

\section{Dimensions of follicles and oocytes}

The data were aggregated from young and old animals since the size of follicles and oocytes were independent of age. The diameter of oocytes increased in direct proportion to that of the follicle until the latter had reached approximately $300 \mu \mathrm{m}$ at stage $\mathrm{V}$ when the oocyte had attained 


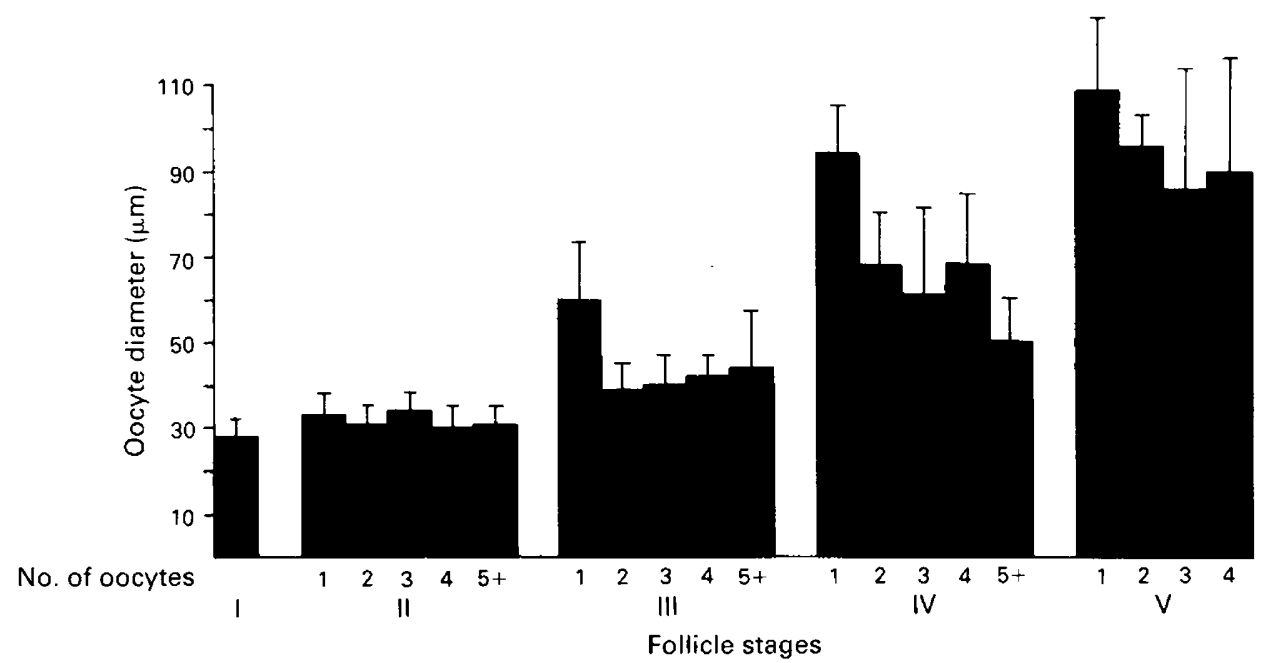

Fig. 5. Variation in the diameters of oocytes in uni- and polyovular follicles at different stages of development in bitch ovaries. Values are means + s.e.m.

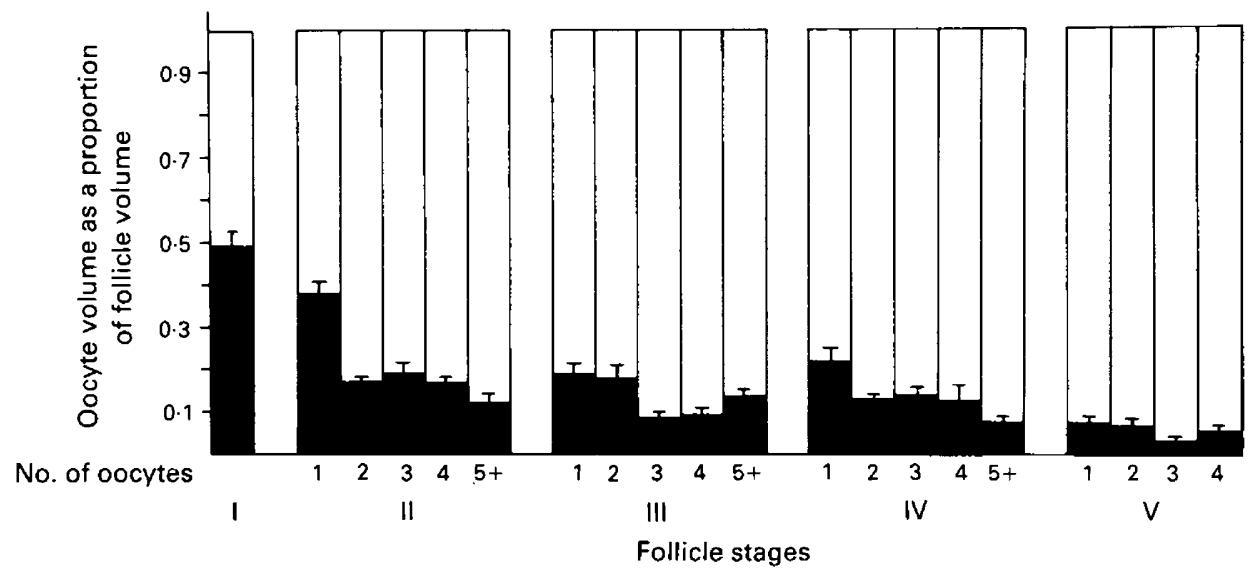

Fig. 6. The proportion of follicle volume occupied by the oocyte(s): variation with the stage of development and the numbers of oocytes per follicle. Values are mean and s.d. because the s.e. values were too small to be drawn.

its mature size of $90-110 \mu \mathrm{m}$. Whilst the size of oocytes was similar in polyovular follicles at stage II, at subsequent stages it was always greater in uniovular types (Fig. 5). Frequently, the oocytes were packed closely to one another near the geometric centre of the follicle (Fig. 3) but when they were more scattered it appeared that the peripheral oocytes were smaller than the central ones.

Polyovular follicles were substantially larger than uniovular types at the same stage of development. This difference, which was $2-3$-fold in volume, could be accounted for by both a greater volume of oocytes in toto and larger numbers of granulosa cells. The granulosa cell volume was deduced from the difference between the follicle volume and the total volume of oocyte(s) on the assumption that the volume of individual granulosa cells is constant and that there is little extracellular space at preantral stages. Despite the smaller sizes of individual oocytes the total volume in polyovular follicles was increased. The relationship between the volume of the oocyte(s) 
and that of the follicle was not constant and when expressed as proportions there was a tendency for the granulosa cell component to rise during development (Fig. 6). The proportion occupied by oocytes was greatest at stage II for uniovular follicles, this being significantly greater than in comparable polyovular types $(P<0.05)$. At later stages the proportions were relatively even between types.

\section{Discussion}

The quantitative profile of follicles in the bitch ovary conveys the impression that polyovular development is neither a spurious nor a pathological phenomenon but is a natural polymorphism arising from a spectrum of possible numerical combinations of oocytes and pregranulosa cells. Uniovular development is the dominant mode in all species investigated but polyovuly is widely distributed albeit at varying frequencies (see also Bocharov, 1966; Mossman \& Duke, 1973).

These new data are consistent with, but do not prove, the hypothesis that polyovular follicles are predetermined during folliculogenesis. Concrescence was not observed between growing follicles and this possibility is apparently denied by the stable or falling incidence of polyovuly at successive stages. A third explanation for the presence of polyovular follicles proposes that either polynucleate or mononucleate oocytes divide (Hartman, 1926; Iguchi et al., 1986) but this can be refuted in the present examples because of a deficiency of the former with a lack of excess numbers of follicles with an even number of oocytes. Whilst there is circumstantial evidence for the predetermination of polyovular follicles the latter cannot be claimed to pre-exist in the primordial follicle pool since there is neither cytological nor physiological evidence of intercellular metabolic coupling. Light microscopy gives only a suggestion of physical intimacy between oocytes but fine structural details must be clarified if the possibility of synchronous development is to be inferred. Cortical oocytes occur in dense plaques in young ovaries of species having abundant polyovular follicles, but density-dependence cannot be the only causal factor since intimately clustered oocytes occur in some species which rarely present polyovuly (e.g. sheep).

One of the striking features of the data is the inverse relationship between the numbers of oocytes per follicle and the numbers of follicles. The frequency distribution suggests that a stochastic process has been operating although this hypothesis cannot be verified in the adult ovary since utilization and death of follicles has modified the original population and, additionally, incipient polyovular follicles cannot be identified. The conclusion that polyovuly arises from random events during folliculogenesis conflicts with most of the suggestions in the older literature. On the basis of early claims that polyovular follicles were less common after puberty than in the immature ovary (Davis \& Hall, 1950; Dawson, 1951; Bodemer \& Warnick, 1961b) some workers obtained evidence that the incidence of these follicles depends upon the balance of sex steroids and pituitary gonadotrophins (Kent, 1959; Graham \& Bradley, 1971). The present results do not deny a possible role for these hormones, but the predetermination hypothesis proposes an explanation for polyovuly on the basis of cellular interactions occurring during folliculogenesis which may or may not depend on sex steroids and the gonadotrophins.

Polyovular follicles are less common in older bitches than in animals beginning their reproductive life: they are fewer in number and comprise a lower percentage of the growing follicle population. As more specimens become available it will be interesting to determine whether polyovular follicles become progressively more sparse throughout life. Whilst the probability of finding a binovular follicle was only slightly reduced during ageing, those for types 3 and 4 were considerably lower and other types were entirely absent. Since the animals were anoestrous it is unclear whether there is a hormonal basis for these findings. The age effect could be due to a reduced frequency of predetermined polyovular follicles in the reserve pool as a result of increased utilization at young ages and/or decreased viability of follicles entering their growth phase. The nature of the stimulus that prompts primordial follicles to start growing is not known, although it is 
widely assumed to be a spontaneous event. If it is conjectured that this event occurs independently in oocytes and that activation can be transmitted to physiologically coupled oocytes it is to be expected that the probability of utilization will vary with the number of oocytes within a follicle. This model is in accord with the observed changes in the follicle profile. On the other hand, the diminishing frequency of polyovular follicles at each successive stage of growth suggests that they are less viable in old ovaries. The environment of the ageing ovary may be less capable of providing physiological support for the growth of follicles, and this is consistent with the observed higher incidence of follicle death.

Oocytes.in polyovular follicles start their development at a size similar to that of oocytes in uniovular follicles. Size differences emerge, however, at stage III when two granulosa cell layers are present but the oocytes undergo morphologically normal development. This may suggest some developmental lagging but it could also be argued that the stages of uni- and polyovular follicles are not comparable. This hypothesis is difficult to evaluate from a morphological approach.

Polyovular follicles were larger than uniovular types at the same stage and it will be interesting to determine whether these differences continue into the antral stages. The number of granulosa cells inferred from measurements of follicle and oocyte volumes rose pari passu with the total mass of oocyte(s), which may indicate that cellular interactions are co-ordinating the growth of the compartments. There would appear from the morphological evidence to be no reason to suspect that oocytes in young ovaries are much less viable in polyovular follicles compared with the norm and other studies have shown that they can reach preovulatory maturity, each being enclosed in separate cumuli oophori (Dederer, 1934; Davis \& Hall, 1950; Andersen \& Simpson, 1973).

In addition to the problem of ontogenesis, polyovular follicles have attracted interest because of their potential contribution to the quota of oocytes shed at ovulation and, hence, to the speciescharacteristic litter size. According to the present results this contribution is expected to be small even in species having relatively abundant polyovular follicles and it is likely to be virtually nil in older animals. The quantitative significance of these follicles can be illustrated by a simplified example. If it is assumed that all oocytes in stage $\mathrm{V}$ follicles are equally viable and that the selection of dominant follicles is random, the chance of ovulating a polyovular follicle of any type would be a product of their incidence at that stage and the number of follicles selected for ovulation. We can see from the data that the pool of follicles available for ovulation contains 10 times as many uniovular follicles as polyovular follicles. Assuming that the mean ovulation rate in the bitch is four and using the values obtained for follicle type at stage $\mathrm{V}$, we can estimate that the probability of one binovular follicle being ovulated will be 0.06 . Because estimates based on the mixed group of follicles at stage $\mathrm{V}$ do not represent the ovulatory pool of follicles, any probability values are likely to be overestimates. In view of these predictions and the observed age change it appears that the rising fecundity during the first half of the reproductive lifespan, as measured by the frequency of dizygotic twins in women (Bulmer, 1970) and the successively larger litters in young parous mice (Kennedy \& Kennedy, 1972), is probably due to a higher ovulation rate rather than the contribution of polyovular follicles.

We thank the Wellcome Trust and the Medical Research Council for grants; Dr Janet Nicholson for many of the specimens; Kay Grant for excellent technical assistance; and Dr Malcolm Faddy for helpful suggestions.

\section{References}

Andersen, A.C. \& Simpson, M.E. (1973) The Ovary and the Reproductive Cycle of the Dog (Beagle). Geron-X Inc., Los Altos, California.

Bocharov, W.S. (1966) Multiovular follicles in the ovaries of mammals. Adv. Sov. Biol. 62, 139-147.
Bodemer, C.W. \& Warnick, S. (196la) Polyovular follicles in the immature hamster ovary. II. The effects of gonadotropic hormones on polyovular follicles. Fert. Steril. 12, 353-364.

Bodemer, C.W. \& Warnick, S. (1961b) Polyovular fol- 
licles in the immature hamster ovary. I. Polyovular follicles in the normal intact animal. Fert. Steril. 12, 159-169.

Bulmer, M.G. (1970) The Biology of Twinning in Man. Oxford University Press, London.

Davis, D.E. \& Hall, O. (1950) Polyovuly and anovular follicles in the wild Norway rat. Anat. Rec. 107, 187-192.

Dawson, A.B. (1951) Histogenetic interrelationships of oocytes and follicle cells. A possible explanation of the mode of origin of certain polyovular follicles in the immature rat. Anat. Rec. 110, 181-197.

Dederer, P.H. (1934) Polyovular follicles in the cat. Anat. Rec. 60, 391-396.

Gosden, R.G. \& Telfer E. (1987) Numbers of follicles and oocytes in mammalian ovaries and their allometric relationships. J. Zool., Lond. 211, 169-175.

Graham, C.E. \& Bradley, C.F. (1971) Polyovular follicles in squirrel monkeys after prolonged diethylstilboestrol treatment. J. Reprod. Fert. 27, 181-185.

Hartman, C.G. (1926) Polynuclear ova and polyovular follicles in the opossum and other mammals with the special reference to the problem of fecundity. $A m . J$. Anat. 37, 1-52.

Iguchi, T., Takasugi, N., Bern, H.A. \& Mills, K.T. (1986) Frequent occurrence of polyovular follicles in ovaries of mice exposed neonatally to diethyl stilbestrol. Teratology 34, 29-35.
Kennedy, T.G. \& Kennedy, J.P. (1972) Effects of age and parity on reproduction in young female mice. $J$. Reprod. Fert. 28, 77-84.

Kent, H.A., Jr (1959) Reduction of polyovular follicles and polynuclear ova by oestradiol monobenzoate. Anat. Rec. 134, 455-462.

Kent, H.A., Jr (1960) Polyovular follicles and multinuclear ova in ovaries of young mice. Anat. Rec. 137, 521-524.

Kent, H.A., Jr \& Mandel, J.A. (1970) Correlation of ovarian abnormalities in young golden hamsters with ovarian oestrogen and progésterone. Anat. Rec. 168, 233-236.

Lane, C.E. (1938) Aberrant ovarian follicles in the immature rat. Anat. Rec. 71, 243-247.

Mandl, A.M. \& Zuckerman, S. (1951) Numbers of normal and atretic oocytes in unilaterally spayed rats. $J$. Endocr. 7, 112-119.

Mossman, H.W. \& Duke, K.L. (1973) Comparative Morphology of the Mammalian Ovary. University of Wisconsin, Madison, Wisconsin.

Swyte, D.A. \& Rosberry, F.W. (1977) A comparison of some optical microscope measurements of photomask linewidths. Solid State Technol. August, 70-75.

Von Baer, K.E. (1827) De ovi mammalium et hominis genesi. Epistola ad Acad. Imper. Sci. petropolitanam. L. Vossi Leipzig.

Received 19 January 1987 